\title{
Video Article \\ Enactive Phenomenological Approach to the Trier Social Stress Test: a mixed methods point of view
}

\author{
Oliver Vors ${ }^{1}$, François Cury ${ }^{1}$, Tanguy Marqueste ${ }^{1}$, Nicolas Mascret ${ }^{1}$ \\ ${ }^{1}$ Aix-Marseille Université, Centre National de la Recherche Scientifique (CNRS), Institut des Sciences du Mouvement (ISM)
}

Correspondence to: Oliver Vors at olivier.vors@univ-amu.fr

URL: https://www.jove.com/video/58805

DOI: doi: $10.3791 / 58805$

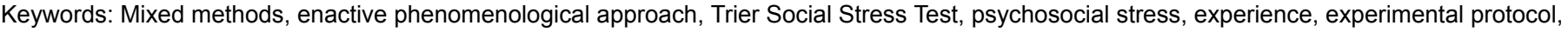
HPA axis, cortisol, anxiety

Date Published: $11 / 30 / 2018$

Citation: Vors, O., Cury, F., Marqueste, T., Mascret, N. Enactive Phenomenological Approach to the Trier Social Stress Test: a mixed methods point of view. J. Vis. Exp. (), e58805, doi:10.3791/58805 (2018).

\section{Abstract}

The single Trier Social Stress Test (TSST) and the TSST for groups (TSST-G) are the most used protocols to experimentally induce psychosocial stress. These tests are based on uncontrollability and social-evaluative threat, inducing psychological and physiological consequences (e.g., anxiety, emotional states, salivary cortisol increases). Many quantitative experimental studies have investigated these stress inducers and these consequences. But, as far as we know, this study is the first to provide a qualitative analysis to access the participants' voices so as to understand the dynamics of their experience throughout the TSST and the TSST-G. This paper outlines a mixed methods approach to the TSST. This approach can help to maximize the information that can be gained from the TSST, which researchers often use without looking more closely at what is qualitatively happening psychologically for participants during the stressor itself. In this way, this protocol is an example of mixed methods, showing the added value of using the enactive phenomenological approach to analyze experimental protocols more deeply. This kind of mixed methods is helpful to access the experience, to understand the actor's point of view, and to analyze in-depth the dynamics of cognitive processes like intentions, perceptions, enacted knowledge, and emotion. The discussion section shows the different uses of a mixed methods protocol, exploiting the enactive phenomenological approach to analyze a protocol or to give a cross vision of the same research subject. This section deals with different existing applications, pointing out some critical steps in this mixed methods approach.

\section{Video Link}

The video component of this article can be found at https://www.jove.com/video/58805/

\section{Introduction}

Mixed methods give various advantages when trying to understand a phenomenon ${ }^{1,2,3,4,5}$. Greene et al. ${ }^{6}$ define them as protocols that include a quantitative method to analyze numbers and a qualitative method to analyze words. This approach aims to move beyond paradigm wars or conflicts between qualitative and quantitative research. The goal is to increase the strengths of studies and diminish the weaknesses of single studies $^{3}$; thus, it functions as a third research paradigm. Combining different kinds of analyses on the same object makes it possible to have different points of view. This paper presents a particular form of mixed methods, combining an experimental protocol with experiential data using the single TSST ${ }^{7}$ and the TSST-G ${ }^{8}$. The TSST is the most used protocol to experimentally perform psychosocial stress investigations ${ }^{9,10}$. These tests are based on uncontrollability and social-evaluative threat, linked with physiological and psychological consequences. Different empirical, theoretical, or meta-analysis studies ${ }^{11}$ have shown that the TSST and the TSST-G elicit psychological effects and activate the HPA axis, leading, for example, to negative emotional states, self-reported anxiety, and cortisol rise. Many experimental studies investigated these markers of stress, their relations, and their influences ${ }^{12}$. However, only one qualitative approach has been conducted ${ }^{13}$ to understand the participants' lived experiences during these tests.

The present protocol develops the original mixed methods approach mainly used in an earlier publication ${ }^{13}$. The originality of this mixed methods research lies in the qualitative approach based on an enactive phenomenological framework ${ }^{13,14,15,16}$ to examine accurately participants' experiences when confronted with the TSST and the TSST-G. Qualitative investigations can be heuristic because they make it possible to characterize and analyze what is happening psychologically for participants in a particular situation ${ }^{17}$. Last, the enactive phenomenological approach allows researchers to understand the participants' points of view and, thus, to analyze stress and emotion ${ }^{18,19,20}$. Following this approach, participants can describe, comment on, and show their lived experience step-by-step. This enactive phenomenological framework has two main assumptions ${ }^{16,21}$. First, action and situation are coupled ${ }^{22,23}$ (i.e., the dynamics of the action emerge within a specific context). This assumption provides access to the dynamics of the participant's experience confronted with the TSST and the TSST-G and to identify particular components of the context for the actor. Secondly, every action carries significations for the actor ${ }^{23,24}$. This approach provides access to the actor's signification construction of the experience during the action, thanks to a rigorous method originating from phenomenological interviews and named enactive interviews ${ }^{16,25}$. The actor's experience can be characterized in its emotional, perceptional, and situational dimensions ${ }^{26}$. Different kinds of mixed methods are based on this enactive phenomenological approach, which has already produced heuristic results in different areas, namely sport ${ }^{14,15,18,27}$, doping ${ }^{28}$, work $^{29}$, and education ${ }^{30,31,32}$. 
The mixed methods presented here aim to give confirmation and comprehension to findings in the TSST literature: confirmation through a comparison of the effect of the TSST and the TSST-G on physiological indicators (like cortisol), on self-reported indicators (like anxiety and emotional states), and on experiential indicators (like participants' voices) and comprehension through the qualitative method accessing participants' dynamics of action as they emerge in these stressful protocols. This is an original way to access in-depth the dynamics of psychosocial stress and to understand the participants' voices about the stressful moment of the TSST and the TSST-G. This protocol is, thus, an example of mixed methodology, showing the added value of using the enactive phenomenological approach to analyze the experimental protocol more deeply.

\section{Protocol}

The Institutional Review Board of the University approved this research.

NOTE: An example of mixed methods using the enactive phenomenological protocol.

\section{Exclusion Criteria}

1. Use a questionnaire before the experiment in order to exclude some participants, as necessary, on the following criteria: smoking (over five cigarettes per day), drinking (over two glasses of alcohol per day), taking medication, using drugs, having an endocrine problem, experiencing chronic stress (e.g., as determined by the French version of the Perceived Stress Scale [PSS]) ${ }^{33}$, and experiencing psychological distress (e.g., as determined by the French version of the General Health Questionnaire [GHQ-12] ${ }^{34}$.

\section{Preliminary Instructions}

NOTE: The following preliminary instructions need to be given 1 day before the experimentation.

1. Tell the participants not to take any medication, perform physical exercises, or consume alcohol the day before the test.

2. Tell the participants to wake up at least $3 \mathrm{~h}$ before the test.

3. Tell the participants to not drink or eat anything, smoke, or brush their teeth $1 \mathrm{~h}$ before the test.

\section{Pretest Measurements}

NOTE: The protocol presented in this section was used in the earlier publication mentioned in the introduction ${ }^{13}$. Prestress measurements can be done after an inactive wait of $45 \mathrm{~min}^{10}$; also, the first point of measure can be done 20 min before the TSST ${ }^{35}$.

1. First saliva collection

NOTE: Salivary cortisol is commonly used as a physiological marker of stress with the TSST ${ }^{9,36}$

1. Use the passive drool method: ask the participant to tilt their head forward to allow saliva to pool in their mouth, and instruct them to guide it into a small polypropylene tube.

2. Freeze the tube immediately at $-20^{\circ} \mathrm{C}$.

\section{First questionnaire collection}

1. Measure the participant's anxiety. Ask them to fill out the State-Trait Anxiety Inventory (STAI) ${ }^{37}$ questionnaire.

NOTE: STAI is an example of a questionnaire that can be used to measure anxiety. It is a Likert scale with a range of four options $(1=$ not at all, 4 = very much so); using this range, participants were asked to respond to 12 items (e.g., "I feel tense"). A composite variable was constructed with the scores of all items.

2. Measure the participant's emotional state. Ask them to fill out the Self-Assessment Manikin (SAM) ${ }^{38}$ questionnaire.

NOTE: SAM is a Likert scale that uses a nonverbal pictorial technique with nine figures to evaluate pleasure, arousal, and dominance. Participants have to circle a figure for each item.

3. Then, bring the participant into the TSST room.

\section{Performance of the TSST or the TSST-G}

NOTE: Different aspects of the TSST have already been described in other JoVE $\operatorname{articles}^{10,12,39}$.

\section{Protocol context}

1. Position the participant in the protocol room on a red cross drawn on the floor.

2. Question the participants one by one for the TSST.

3. Use a group of participants (e.g., six participants separated by little walls to limit social and visual interaction ${ }^{13}$ ) for the TSST-G.

4. Ensure that the experimenters (two or three) are neutral and look like scientists with white lab coats.

5. Explain that the committee members are specialists in nonverbal behavior analysis and all actions are filmed for future analysis.

\section{Mock job interview}

1. Ask the participant to imagine a job of their choice.

2. Give the participant $3 \mathrm{~min}$ of preparation time (10 $\mathrm{min}$ for the TSST-G).

3. Specify that preparation notes cannot be used during the interview.

4. Give the participant 5 min of presentation time ( 2 min for the TSST-G, performed in random order) in front of the committee to explain why they are the best candidate for this job. 
5. Tell the participant to continue when they stop talking by saying "You still have time remaining."

6. Remain silent for $20 \mathrm{~s}$ when that participant stops talking for the second time.

7. Ask standardized questions if the participant does not resume speaking (e.g., "Please list your weaknesses.").

\section{Mental arithmetic task}

1. Ask the participant to count aloud backward from 2023 in steps of 17. For the TSST-G, the numbers are different for each participant.

2. Explain the participant they must calculate as quickly and correctly as possible.

3. Point out each mistake and tell the participant to start all over again.

4. Make sure the task lasts $5 \mathrm{~min}$ ( $80 \mathrm{~s}$ for the TSST-G, performed in random order).

\section{Posttest Measurements}

NOTE: Then, collect a second saliva sample and let the participant complete questionnaires in another room (same process as the first collections, described in section 3 of this protocol).

1. Second saliva collection

NOTE: The measurement of cortisol levels is repeated (6 to 9 times) to analyze the cortisol response.

1. Following the passive drool method, collect saliva from the participant into a small polypropylene tube, as described previously (step 3.1.1).

2. Freeze the tube immediately at $-20^{\circ} \mathrm{C}$.

\section{Second questionnaire collection}

1. Measure the anxiety. Ask the participant to fill out the STAI ${ }^{37}$ questionnaire.

NOTE: STAI is a Likert scale with a range of four items ( $1=$ not at all, $4=$ very much so); using this range, participants responded to 12 items (e.g., "I feel tense"). A composite variable was constructed with the scores of all items.

2. Measure emotional states. Ask the participant to fill out the $\mathrm{SAM}^{38}$ questionnaire.

NOTE: SAM is a Likert scale that uses a nonverbal pictorial technique with nine figures to evaluate pleasure, arousal, and dominance. Participants have to circle a figure for each item.

\section{Qualitative Investigations}

1. Use a wide-angle camera to record the participant's behavior and their interaction during the TSST or the TSST-G.

2. Conduct enactive interviews to access the participant's experience.

1. Perform the interview as soon as possible after the performance of the TSST or the TSST-G to ensure the participant still remembers (preferably within $48 \mathrm{~h}$ ).

2. Explain that the participant must relive the past activities, helped by their own audio-visual record of the TSST or the TSST-G. Avoid stating the precise aim of the experiment to the participant.

3. Select an experienced rater who is used to conducting enactive interviews.

4. Confront the participant with their own recording to help them relive the experience as close as possible.

5. Ask directive questions to help the re-emergence of the past experience. For instance, point at an image from the video and ask: "What are you doing here?"

6. Help the participant to remember with questions focused on the video to allow them to describe, comment on, and show their lived experience step by step: "What is happening here on the video?"

7. Investigate the experience's components as intentions and perceptions by asking: "What were your intentions here?", "What did you perceive at this precise moment?"

8. Stop the participant if they use global discourse, a posteriori analysis, or generalization, or when they digress from the precise moment that is being discussed, as suggested for phenomenological research ${ }^{40}$.

9. Ask follow-up questions based on the participant's response. For example, when the participant says: "I am out", ask "What does 'I am out' mean?" and, then, continue to investigate what happens from the participant's point of view.

10. Respect the time sequence of the video and avoid changing the time-flow to access the dynamics of the experience step by step.

11. Allow the participant to pause the video when they want to describe their own experience.

\section{Data Analysis}

1. Perform a saliva analysis.

1. Determine the participant's cortisol level by the enzyme-linked immunosorbent assay (ELISA) technique using assay kits (see Table of Materials).

2. Measure the concentration related to the absorbance at $450 \mathrm{~nm}$ with a 96-well microplate spectrophotometer (see Table of Materials).

3. Calculate the intra-assay precision with the average value of individual variability for all of the duplicates within each microplate.

4. Obtain concentrations of unknown samples ( $\mathrm{nmol} / \mathrm{L}$ ) with a four-parameter nonlinear regression curve fit, following the ELISA kit protocol recommendations, based on cortisol standards $(82.77,27.59,9.19,3.06,1.02,0.33 \mathrm{nmol} / \mathrm{L})$.

2. Perform a statistical analysis using repeated measures ANOVAs with a level of significance at $p<0.05$.

3. Calculate the effect sizes with a partial eta squared.

NOTE: Eta squared is a statistical measure of effect size for use in ANOVA.

4. Perform a phenomenological analysis. 
1. Transcribe all the enactive interviews with the maximum of detail, such as verbal clutter, demonstration, hesitation, etc.

2. Construct a two-part table that outlines the time flow, transcription, and a report of the behaviors and discussion helped by the recordings (Table 1)

3. Identify components of the experience, beginning with the elementary units of meaning corresponding to the smallest units of activity meaningful to a participant.

4. Identify perception, analyzing the meaningful sensation, sentiment, and informational aspects (visual, acoustic, or kinesthetic) in the situation.

5. Identify intention, analyzing the participant's concern in the situation.

6. Categorize sequences by grouping units of meaning related to the same story.

7. For each participant, identify their typical experience descriptively, statistically, generatively, and significantly ${ }^{21}$ (e.g., typical action, typical intention, and typical perception).

8. Identify the typical experiences of all the participants, finding similarities between each typical experience.

9. Construct tables of typical experience for all the participants, using the following values: timeline, typical sequences, typical perceptions, typical actions, and typical intentions.

10. Normalize the formulation of each category using a group of words to express the typical sequence, an "ing" for the typical action, and an infinitive verb for the typical intention.

11. Compare the TSST and the TSST-G using the two tables of typical lived experience.

12. Present the common aspects of experience during both protocols.

13. Present the singular aspects of experience during each protocol.

5. Perform a case study analysis to understand the local processes, for example, the four lowest and highest cortisol responders.

1. Identify the components of the experience (see the preceding protocol).

2. Rebuild the meaningful experience for each participant following the TSST or the TSST-G steps.

6. Compare the mixed methods

1. Compare the quantitative and qualitative results conducting analyses and interpretation separately (cortisol, state anxiety, emotional states, experience data).

2. Verify whether the quantitative analysis' results of the stress dynamics are similar to those of the qualitative analysis

3. Analyze whether what happened in the participants' experiences can help in understanding quantitative stress variation.

\section{Representative Results}

The results shown here come from a review of literature (for the cortisol) ${ }^{8}$ and two studies on stress done in our lab (for the state anxiety, the affective reaction, and the qualitative approach $)^{13,41}$. The results presented here are representative of what can be found, using the protocol, about (1) salivary cortisol levels, (2) state anxiety, (3) pleasure, arousal, and dominance, and (4) meaningful experience.

First, the results below are an example of a quantitative analysis of stress with salivary cortisol as physiological marker ${ }^{8}$. They show the dynamics of the salivary cortisol rises for a group confronted with the TSST and a control group (Figure 1).

Second, the results below are an example of a quantitative analysis of stress consequences, with the STAI scale as an indicator of stress anxiety, a psychological marker of stress ${ }^{41}$. They show the dynamics of state anxiety during the TSST and the placebo-TSST with four points of measure (baseline, $\mathrm{t}-2 \mathrm{~min}$ before the TSST, $\mathrm{t}+2 \mathrm{~min}$ after the TSST, and $\mathrm{t}+20 \mathrm{~min}$ after the TSST) (Figure 2). The Placebo-TSST is a protocol similar to the TSST without causing stress for the participants ${ }^{42}$.

Third, the results below are an example of a quantitative analysis of stress with the SAM $^{38}$ scale as indicator of 'affective reaction', a psychological marker of stress ${ }^{41}$. They show the dynamics of pleasure, arousal, and dominance during the TSST and the placebo-TSST (Figure 3).

Four, the results below are an example of a qualitative approach to lived stress based on an enactive phenomenological framework ${ }^{13}$. Also, the typical experience of participants can be described during the TSST (Table 2) and the TSST-G (Table 3).

This particular mixed methods approach has different functions here: confirmation, comprehension, and development. The results show a confirmation of the increase of stress measured with physiological indicators (like cortisol), with self-reported indicators (like anxiety and emotional states), and with experiential indicators (like the participants' voices).

Mixed methods allow the comprehension of stress manifestations during the TSST and the TSST-G, accessing the participants' dynamics of action. For example, the quantitative results show a similar level of stress between the TSST and the TSST-G participants. The qualitative results show common lived experiences, such as each participant beginning with an exploratory investigation, in which they state they are surprised by the uncommon environment. Common sequences appear in the mock job interview (Recitation, Expanding on ideas, Time pressure, Loss of control, Paradoxical liberation) and in the mental arithmetic task (Calculation disturbed, Negative Spiral, Seeking solutions, Abandonmentresignation, Paradoxical liberation), giving details about the perception, action, and intention of the participants for each phase. The level of comprehension allowed by mixed methods goes deeper with the different singular typical experiences. The quantitative methods do not show differences between the TSST and the TSST-G, but the qualitative methods show some singular experiences between these stressful protocols. For example, stress fluctuation, temporality, and the presence of peers are not experienced in the same way in the TSST and the TSST-G. This "comprehensive picture" ${ }^{3}$ can be taken further with case studies of high and low cortisol responders ${ }^{43}$.

Finally, the mixed methods approach presented here has a development function for the research, in that the findings provide by one method can be used to modify the other ${ }^{6}$. For example, qualitative methods show some important moments in the dynamics of the participant's actions. It could be interesting to measure the level of stress with quantitative methods in these specific moments. 


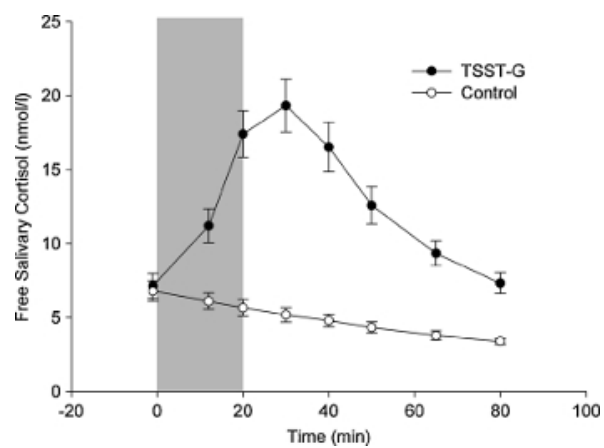

Figure 1: Cortisol reactivity to the TSST-G. Mean salivary cortisol levels before, during (shaded area), and after a standardized psychosocial stressor in a group format (Trier Social Stress Test for Groups [TSST-G]) and a control condition. The error bars are the SEM ${ }^{8}$.This figure has been modified from Von Dawans et al. ${ }^{8}$. Please click here to view a larger version of this figure.

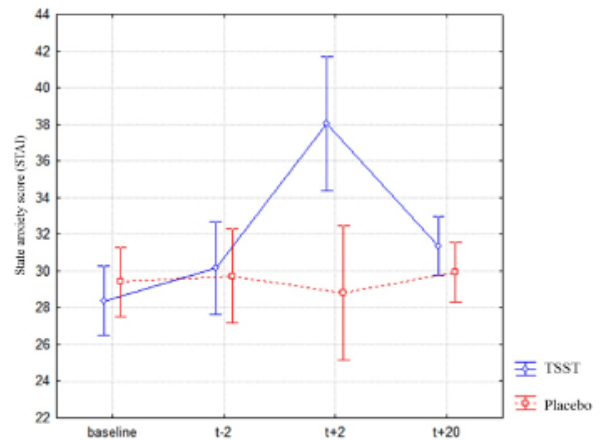

Figure 2: Anxiety reaction to the TSST. The state of anxiety of the participants exposed to the two treatments (TSST and placebo-TSST) measured with the STAI ${ }^{41}$. This figure has been modified from Mascret et al. ${ }^{41}$. Please click here to view a larger version of this figure.
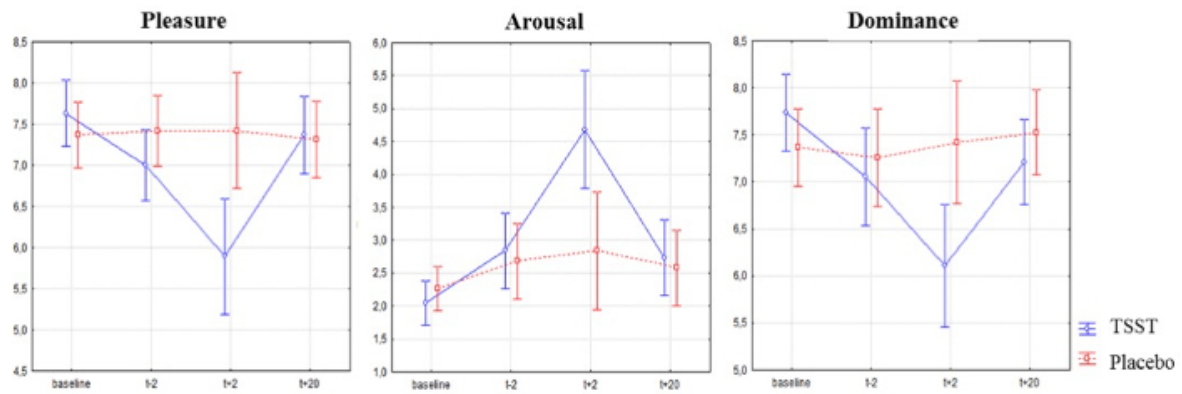

Figure 3: Affective reaction to the TSST. Pleasure, arousal, and dominance of the participants exposed to the two treatments (TSST and placebo-TSST) measured with the SAM ${ }^{41}$. This figure has been modified from Mascret et al. ${ }^{41}$. Please click here to view a larger version of this figure.

\begin{tabular}{|l|l|l|}
\hline Time & Description of action and communication & Verbatim of enactive interview \\
\hline $5 \mathrm{~min}$ & $\begin{array}{l}\text { François enters the experimental room. He is } \\
\text { looking around, staying quiet. }\end{array}$ & $\begin{array}{l}\text { François: Oh, yes, at this moment...er... (he } \\
\text { points to his image on the video) I'm thinking, } \\
\text { where I am... ouch... that's strange. } \\
\text { Researcher: what are you doing here? } \\
\text { François: I'm waiting, I say to myself 'What } \\
\text { have I got myself into here?' I didn't think it } \\
\text { would be like this. I'm out of my... comfort zone } \\
\text { (he touches his head, looking lost). "What's } \\
\text { going to happen?... I'm in an observation } \\
\text { phase... it's weird.... A really strange situation } \\
\text { for me. I don't like being destabilized. I like to } \\
\text { have things announced well in advance. }\end{array}$ \\
\hline
\end{tabular}

Table 1: Example of the two-part table. 


\begin{tabular}{|c|c|c|c|c|c|}
\hline & Situation & SEQUENCES & Perceptions & Actions & Intentions \\
\hline Job interview task & $\begin{array}{l}\text { Entering the room } \\
\text { Explanation of } \\
\text { instructions }\end{array}$ & $\begin{array}{l}\text { Exploratory } \\
\text { investigation }\end{array}$ & $\begin{array}{l}\text { Surprise } \\
\text { Generally tense } \\
\text { atmosphere }\end{array}$ & $\begin{array}{l}\text { Im listening } \\
\text { I'm observing }\end{array}$ & Try to understand \\
\hline Job interview task & $\begin{array}{l}\text { Preparation phase } \\
3 \text { minutes }\end{array}$ & Preparation & $\begin{array}{l}\text { Time pressure } \\
\text { Preparing }\end{array}$ & $\begin{array}{l}\text { I'm organizing my } \\
\text { presentation }\end{array}$ & $\begin{array}{l}\text { Find and select ideas } \\
\text { Keep within the time }\end{array}$ \\
\hline Job interview task & Interview phase & 1) Recitation & $\begin{array}{l}\text { Reassured to be doing } \\
\text { what is planned }\end{array}$ & I'm reciting & $\begin{array}{l}\text { Repeat the prepared } \\
\text { introduction }\end{array}$ \\
\hline Job interview task & $\begin{array}{l}\text { Preparation phase } \\
3 \text { minutes }\end{array}$ & 2) Expanding on ideas & $\begin{array}{l}\text { Stressed by } \\
\text { hesitations and } \\
\text { memory lapses }\end{array}$ & $\begin{array}{l}\text { I'm expanding on the } \\
\text { ideas I've planned }\end{array}$ & $\begin{array}{l}\text { Retrieve and state the } \\
\text { ideas I have prepared } \\
\text { Convince the } \\
\text { committee }\end{array}$ \\
\hline Job interview task & $\begin{array}{l}\text { Preparation phase } \\
3 \text { minutes }\end{array}$ & 3) Time pressure & $\begin{array}{l}\text { Anxiety on seeing how } \\
\text { much time is left }\end{array}$ & $\begin{array}{l}\text { I'm watching the } \\
\text { countdown }\end{array}$ & Know how far l've got \\
\hline Job interview task & $\begin{array}{l}\text { Preparation phase } \\
3 \text { minutes }\end{array}$ & $\begin{array}{l}\text { 4) Loss of control: } \\
\text { Nothing more to say }\end{array}$ & $\begin{array}{l}\text { Feel observed, judged } \\
\text { Uncomfortable about } \\
\text { saying whatever } \\
\text { comes into my head } \\
\text { Time perceived as } \\
\text { interminable }\end{array}$ & $\begin{array}{l}\text { I can't think any more } \\
\text { I'm searching } \\
\text { chaotically } \\
\text { I'm hesitating, I'm } \\
\text { stuttering, I'm leaving } \\
\text { gaps } \\
\text { I'm constantly glancing } \\
\text { at the time left }\end{array}$ & $\begin{array}{l}\text { Fill the time } \\
\text { Avoid gaps } \\
\text { Look for support }\end{array}$ \\
\hline Job interview task & $\begin{array}{l}\text { Preparation phase } \\
3 \text { minutes }\end{array}$ & $\begin{array}{l}\text { 5) Abandon, } \\
\text { resignation }\end{array}$ & $\begin{array}{l}\text { Sense of } \\
\text { incompetence } \\
\text { Sense of looking } \\
\text { incompetent }\end{array}$ & $\begin{array}{l}\text { I'm losing my grip } \\
\text { I'm doing nothing, I'm } \\
\text { keeping quiet }\end{array}$ & Wait for it to end \\
\hline Job interview task & $\begin{array}{l}\text { Preparation phase } \\
3 \text { minutes }\end{array}$ & 6) Detachment & $\begin{array}{l}\text { Realize it's not } \\
\text { important }\end{array}$ & $\begin{array}{l}\text { I'm laughing } \\
\text { I'm laughing at myself }\end{array}$ & Try to reassure myself \\
\hline Job interview task & $\begin{array}{l}\text { Preparation phase } \\
3 \text { minutes }\end{array}$ & $\begin{array}{l}\text { 7) Paradoxical } \\
\text { liberation }\end{array}$ & $\begin{array}{l}\text { Hear beep at end of } \\
\text { countdown } \\
\text { Relief } \\
\text { Sense of failure }\end{array}$ & $\begin{array}{l}\text { I'm relaxing } \\
\text { I'm staying } \\
\text { concentrated for the } \\
\text { second task }\end{array}$ & $\begin{array}{l}\text { Self-evaluate } \\
\text { Worry about what the } \\
\text { committee will think of } \\
\text { me }\end{array}$ \\
\hline Mental arithmetic task & $\begin{array}{l}\text { Explanation of } \\
\text { instructions }\end{array}$ & $\begin{array}{l}\text { Exploratory } \\
\text { investigation }\end{array}$ & $\begin{array}{l}\text { Pressure increasing } \\
\text { Sense of relative } \\
\text { easiness }\end{array}$ & $\begin{array}{l}\text { I'm listening to the } \\
\text { instructions }\end{array}$ & Try to understand \\
\hline Mental arithmetic task & $\begin{array}{l}\text { Calculation phase } \\
5 \text { minutes }\end{array}$ & $\begin{array}{l}\text { 1) Calculation } \\
\text { disturbed }\end{array}$ & $\begin{array}{l}\text { Under time pressure } \\
\text { Ashamed of making } \\
\text { mistakes in an easy } \\
\text { task }\end{array}$ & $\begin{array}{l}\text { I'm going fast but } \\
\text { I'm making lots of } \\
\text { mistakes } \\
\text { I'm getting lost: I'm } \\
\text { recalculating several } \\
\text { times }\end{array}$ & $\begin{array}{l}\text { Not make mistakes } \\
\text { Be quick }\end{array}$ \\
\hline Mental arithmetic task & $\begin{array}{l}\text { Calculation phase } \\
5 \text { minutes }\end{array}$ & 2) Negative Spiral & $\begin{array}{l}\text { Feel everything getting } \\
\text { jumbled up in my head } \\
\text { Aware of my negative } \\
\text { thoughts }\end{array}$ & $\begin{array}{l}\text { I can't count any more } \\
\text { I'm making repeated } \\
\text { errors }\end{array}$ & Not look incompetent \\
\hline Mental arithmetic task & $\begin{array}{l}\text { Calculation phase } \\
5 \text { minutes }\end{array}$ & 3) Seeking solutions & Withdraw into self & $\begin{array}{l}\text { I'm looking for } \\
\text { strategies }\end{array}$ & $\begin{array}{l}\text { Find solutions } \\
\text { Not lose face }\end{array}$ \\
\hline Mental arithmetic task & $\begin{array}{l}\text { Calculation phase } \\
5 \text { minutes }\end{array}$ & $\begin{array}{l}\text { 4) Abandonment, } \\
\text { resignation }\end{array}$ & $\begin{array}{l}\text { Fed up, I've had } \\
\text { enough of this } \\
\text { Realize it's too much } \\
\text { for me }\end{array}$ & $\begin{array}{l}\text { I have nothing more to } \\
\text { say } \\
\text { I'm saying whatever } \\
\text { comes into my head }\end{array}$ & Make the time go by \\
\hline Mental arithmetic task & $\begin{array}{l}\text { Calculation phase } \\
5 \text { minutes }\end{array}$ & $\begin{array}{l}\text { 2') Repeated } \\
\text { successes }\end{array}$ & $\begin{array}{l}\text { Only thinking about the } \\
\text { numbers }\end{array}$ & $\begin{array}{l}\text { I'm concentrating } \\
\text { I'm giving one right } \\
\text { answer after another }\end{array}$ & $\begin{array}{l}\text { Not make a mistake } \\
\text { and have to go back to } \\
\text { the start }\end{array}$ \\
\hline Mental arithmetic task & $\begin{array}{l}\text { Calculation phase } \\
5 \text { minutes }\end{array}$ & $\begin{array}{l}\text { 3) Paradoxical } \\
\text { liberation }\end{array}$ & $\begin{array}{l}\text { Hear beep at end of } \\
\text { countdown } \\
\text { Relief } \\
\text { Sense of failure }\end{array}$ & I'm relaxing & $\begin{array}{l}\text { Self-evaluate } \\
\text { Leave }\end{array}$ \\
\hline
\end{tabular}

Table 2: Typical experience of the TSST participants. This table has been modified from Vors et al. ${ }^{13}$. 


\begin{tabular}{|c|c|c|c|c|c|}
\hline & Situation & SEQUENCES & Perceptions & Actions & Intentions \\
\hline Job interview task & $\begin{array}{l}\text { Entering the room } \\
\text { Instructions explained }\end{array}$ & \begin{tabular}{|l} 
Exploratory \\
investigation
\end{tabular} & $\begin{array}{l}\text { Surprise } \\
\text { Generally tense } \\
\text { atmosphere } \\
\text { Embarrassed having } \\
\text { to talk in presence of } \\
\text { others }\end{array}$ & $\begin{array}{l}\text { I'm listening } \\
\text { I'm observing }\end{array}$ & $\begin{array}{l}\text { Try to understand } \\
\text { Worry about what the } \\
\text { others will think of me }\end{array}$ \\
\hline Job interview task & $\begin{array}{l}\text { Preparation phase } \\
3 \text { minutes }\end{array}$ & Preparation & $\begin{array}{l}\text { Time pressure } \\
\text { Reassured to be } \\
\text { preparing }\end{array}$ & $\begin{array}{l}\text { I'm organizing my } \\
\text { presentation }\end{array}$ & $\begin{array}{l}\text { Find and select } \\
\text { convincing ideas }\end{array}$ \\
\hline Job interview task & Others performing & $\begin{array}{l}\text { Alternation } \\
\text {-Phases of exploratory } \\
\text { listening } \\
\text {-Phases of isolation }\end{array}$ & $\begin{array}{l}\text { Stressed by long } \\
\text { unpredictable wait for } \\
\text { my turn } \\
\text { Destabilized or } \\
\text { reassured by others' } \\
\text { performances }\end{array}$ & $\begin{array}{l}\text { I'm listening to parts of } \\
\text { the speeches } \\
\text { I'm putting myself in } \\
\text { my bubble to repeat } \\
\text { my speech }\end{array}$ & $\begin{array}{l}\text { Find and select ideas } \\
\text { Keep within the time }\end{array}$ \\
\hline Job interview task & $\begin{array}{l}\text { Interview phase } \\
2 \text { minutes }\end{array}$ & Pressure spike & $\begin{array}{l}\text { Hear my number } \\
\text { Peak stress: I don't } \\
\text { remember anything }\end{array}$ & $\begin{array}{l}\text { I'm looking at my } \\
\text { number } \\
\text { I'm repositioning }\end{array}$ & $\begin{array}{l}\text { Not make a fool of } \\
\text { myself }\end{array}$ \\
\hline Job interview task & $\begin{array}{l}\text { Interview phase } \\
2 \text { minutes }\end{array}$ & 1) Recitation & $\begin{array}{l}\text { Reassured to be doing } \\
\text { what was planned }\end{array}$ & I'm reciting & $\begin{array}{l}\text { Repeat the prepared } \\
\text { introduction }\end{array}$ \\
\hline Job interview task & $\begin{array}{l}\text { Interview phase } \\
2 \text { minutes }\end{array}$ & 2) Expanding on ideas & $\begin{array}{l}\text { Stressed by } \\
\text { hesitations and things } \\
\text { forgotten }\end{array}$ & $\begin{array}{l}\text { I'm expanding on the } \\
\text { ideas I planned }\end{array}$ & $\begin{array}{l}\text { Retrieve and state the } \\
\text { ideas I have prepared } \\
\text { Convince the } \\
\text { committee }\end{array}$ \\
\hline Job interview task & $\begin{array}{l}\text { Interview phase } \\
2 \text { minutes }\end{array}$ & 3) Time pressure & $\begin{array}{l}\text { Anxious at seeing the } \\
\text { time left }\end{array}$ & $\begin{array}{l}\text { I'm watching the } \\
\text { countdown }\end{array}$ & Know how far l've got \\
\hline Job interview task & $\begin{array}{l}\text { Interview phase } \\
2 \text { minutes }\end{array}$ & $\begin{array}{l}\text { 4) Loss of control: } \\
\text { Nothing more to say }\end{array}$ & $\begin{array}{l}\text { Uneasy at saying } \\
\text { whatever comes into } \\
\text { my head } \\
\text { Feel observed, judged }\end{array}$ & $\begin{array}{l}\text { I can't think any more } \\
\text { I'm searching } \\
\text { chaotically } \\
\text { I'm hesitating, I'm } \\
\text { stuttering, I'm leaving } \\
\text { silences } \\
\text { I'm constantly glancing } \\
\text { at the time left }\end{array}$ & $\begin{array}{l}\text { Fill the time } \\
\text { Avoid gaps } \\
\text { Look for support }\end{array}$ \\
\hline Job interview task & $\begin{array}{l}\text { Interview phase } \\
2 \text { minutes }\end{array}$ & $\begin{array}{l}\text { 5) Paradoxical } \\
\text { liberation }\end{array}$ & $\begin{array}{l}\text { Hear beep at end of } \\
\text { countdown } \\
\text { Relief } \\
\text { Sense of failure }\end{array}$ & $\begin{array}{l}\text { I'm relaxing } \\
\text { I'm staying } \\
\text { concentrated for the } \\
\text { second task }\end{array}$ & $\begin{array}{l}\text { Self-evaluate } \\
\text { Worry about what the } \\
\text { others will think of me }\end{array}$ \\
\hline Job interview task & Others performing & $\begin{array}{l}\text { Alternation } \\
\text {-Phases of } \\
\text { comparative, } \\
\text { empathetic listening } \\
\text {-Phases of relaxation }\end{array}$ & $\begin{array}{l}\text { Relaxation } \\
\text { Feeling a "knot in the } \\
\text { stomach" }\end{array}$ & $\begin{array}{l}\text { I'm comparing what } \\
\text { is being said with my } \\
\text { own performance } \\
\text { I'm sympathizing with } \\
\text { my struggling peers } \\
\text { I'm gloating } \\
\text { I'm thinking of } \\
\text { something else }\end{array}$ & $\begin{array}{l}\text { Compare myself, try to } \\
\text { reassure myself } \\
\text { Relax a bit }\end{array}$ \\
\hline Mental arithmetic task & $\begin{array}{l}\text { Explanation of } \\
\text { instructions }\end{array}$ & $\begin{array}{l}\text { Exploratory } \\
\text { investigation }\end{array}$ & $\begin{array}{l}\text { Pressure rising } \\
\text { Sense of relative } \\
\text { easiness } \\
\text { Stressed by having } \\
\text { to calculate in front of } \\
\text { everyone }\end{array}$ & $\begin{array}{l}\text { I'm listening to the } \\
\text { instructions }\end{array}$ & Try to understand \\
\hline Mental arithmetic task & Others performing & Training & $\begin{array}{l}\text { Stressed by } \\
\text { unpredictable wait for } \\
\text { my turn } \\
\text { Destabilized by other' } \\
\text { performances }\end{array}$ & $\begin{array}{l}\text { I'm trying to do the } \\
\text { sums } \\
\text { I'm assessing the } \\
\text { difficulty of the task }\end{array}$ & Get ready for my turn \\
\hline Mental arithmetic task & $\begin{array}{l}\text { Calculation phase } \\
80 \text { seconds }\end{array}$ & Pressure spike & $\begin{array}{l}\text { Hear my number } \\
\text { Stress spike }\end{array}$ & $\begin{array}{l}\text { I'm looking at my } \\
\text { number } \\
\text { I'm repositioning }\end{array}$ & $\begin{array}{l}\text { Not make a fool of } \\
\text { myself }\end{array}$ \\
\hline
\end{tabular}




\begin{tabular}{|c|c|c|c|c|c|}
\hline Mental arithmetic task & $\begin{array}{l}\text { Calculation phase } \\
80 \text { seconds }\end{array}$ & $\begin{array}{l}\text { 1) Calculation } \\
\text { disturbed }\end{array}$ & $\begin{array}{l}\text { Under time pressure } \\
\text { Ashamed of making } \\
\text { mistakes in an easy } \\
\text { task }\end{array}$ & $\begin{array}{l}\text { I'm going fast but } \\
\text { l'm making a lot of } \\
\text { mistakes } \\
\text { I'm getting lost: I'm } \\
\text { recalculating several } \\
\text { times }\end{array}$ & $\begin{array}{l}\text { Not make mistakes } \\
\text { Be quick }\end{array}$ \\
\hline Mental arithmetic task & $\begin{array}{l}\text { Calculation phase } \\
80 \text { seconds }\end{array}$ & 2) Negative spiral & $\begin{array}{l}\text { Feel everything getting } \\
\text { jumbled up in my head } \\
\text { Aware of my negative } \\
\text { thoughts }\end{array}$ & $\begin{array}{l}\text { I can't count any more } \\
\text { I'm making repeated } \\
\text { mistakes }\end{array}$ & Not look incompetent \\
\hline Mental arithmetic task & $\begin{array}{l}\text { Calculation phase } \\
80 \text { seconds }\end{array}$ & $\begin{array}{l}\text { 2') Repeated } \\
\text { successes }\end{array}$ & $\begin{array}{l}\text { Only thinking about the } \\
\text { numbers }\end{array}$ & $\begin{array}{l}\text { I'm concentrating } \\
\text { I'm giving one right } \\
\text { answer after another }\end{array}$ & $\begin{array}{l}\text { Not make a mistake } \\
\text { and have to go back to } \\
\text { the start }\end{array}$ \\
\hline Mental arithmetic task & $\begin{array}{l}\text { Calculation phase } \\
80 \text { seconds }\end{array}$ & $\begin{array}{l}\text { 3) Paradoxical } \\
\text { liberation }\end{array}$ & $\begin{array}{l}\text { Hear beep at end of } \\
\text { countdown } \\
\text { Relief } \\
\text { Sense of failure }\end{array}$ & I'm relaxing & $\begin{array}{l}\text { Self-evaluate } \\
\text { Leave }\end{array}$ \\
\hline Mental arithmetic task & Others performing & $\begin{array}{l}\text { Alternation } \\
\text {-Phases of } \\
\text { comparative, } \\
\text { empathetic listening } \\
\text {-Phases of relaxation }\end{array}$ & $\begin{array}{l}\text { Relaxation } \\
\text { Feeling a "knot in the } \\
\text { stomach" }\end{array}$ & $\begin{array}{l}\text { I'm comparing what } \\
\text { is being said with my } \\
\text { performance } \\
\text { I'm feeling sorry for my } \\
\text { struggling peers } \\
\text { I'm gloating } \\
\text { I'm thinking of } \\
\text { something else }\end{array}$ & $\begin{array}{l}\text { Compare myself, try to } \\
\text { reassure myself } \\
\text { Relax a bit }\end{array}$ \\
\hline Mental arithmetic task & & End of task & $\begin{array}{l}\text { Relieved but tense and } \\
\text { disappointed }\end{array}$ & I'm relaxing & Leave \\
\hline
\end{tabular}

Table 3: Typical experience of the TSST-G participants. This table has been modified from Vors et al. ${ }^{13}$.

\section{Discussion}

In this article, we present an original mixed methods approach combining an experimental protocol with the enactive phenomenological approach. This kind of mixed methods is helpful to access experience, to understand participants' points of view, and to analyze in depth the dynamics of cognitive processes like intentions, perceptions, enacted knowledge, and emotions.

Mixed methods can be used in different ways. Green et al. ${ }^{6}$ present five functions: triangulation, complementarity, development, initiation, and expansion. A protocol exploiting the enactive phenomenological approach can be heuristic in these functions. Triangulation and complementarity are close to the purposes of confirmation and comprehension already presented in this paper. Triangulation seeks the convergence of the results from the various methods to increase the validity of the investigation. For example, the results presented here show a confirmation of the increase of stress measured with physiological indicators, with self-reported indicators and with experiential indicators. Complementarity seeks an enhancement of the results and the clarification from one method to the other, to increase the relevance of the investigation. For example, qualitative results give illustrations of and clarification about quantitative methods between two points of measure, showing the dynamics of the participants' experience in different sequences, and their typical perception, action, and intention during experiential sequences. As has been seen above, development is another function of mixed methods, using the findings of one method to modify a part of the other as sampling, implementation, and/or measurement decision, to obtain a stronger method. For example, in the presented results, the qualitative methods give a new development of quantitative ones, inviting the multiplication of quantitative points of measure at several moments experienced as important by the participants.

Then, initiation is used to find new perspectives on or contradictions between the two methods to increase the range of results. For example, experiential and biomechanical approaches are combined to analyze a technical device for elite training in swimming ${ }^{44,45}$. The results show a difference between quantitative and qualitative findings. Participants do not perceive the same things as the biomechanical results. These findings open new perspectives to adapt the technical device according to the swimming speed. For example, in the beginning, it is recommended to use a "medium" speed so that the participants can more easily adjust the device. Our lab is also developing this kind of mixed methods with virtual reality, to understand the point of view of the participant in this specific virtual context and to improve protocols. In this way, mixed methods using an enactive phenomenological approach could be heuristic to analyze a protocol or a device. The protocol can be improved by the participants' experience and its dynamics. Case studies help to understand what happens with particular participants. Thus, this kind of mixed methods is useful for adjusting a protocol as the TSST-G; taking time to select the next participant during the task increases the feeling of uncontrollability ${ }^{13}$.

Finally, expansion is another function of mixed methods. Expansion is used to select the most appropriate method from various inquiry components to extend the scope of the results. For example, the enactive phenomenological approach gives an expansion to motor control analysis to investigate perception and action during ice climbing ${ }^{46}$. The quantitative results show a wider range of limb coordination patterns for experts than for beginner climbers. The qualitative results increase the scope of inquiry, showing that these different coordination patterns are linked to the perception of holes in the icefall. 
However, these kinds of mixed methods have some limitations and require vigilance. The power of enactive interview is limited to a specific level of consciousness. This interview allows researchers to access the prereflexive level of consciousness ${ }^{47}$. This level is on the "fringe of consciousness" 48 (i.e., at the interface of conscious and unconscious processes). So, different data like reflex actions or unconscious behaviors cannot be studied. Moreover, this enactive interview is a critical step in the protocol, due to the difficulty of conducting. The rater must have extensive experience to help the re-emergence of past activity through questions about the video and avoid global discourse and a posteriori analysis ${ }^{40}$ (cf. section 6 of the protocol). Lastly, this specific interview and its analysis are time-consuming and limit the number of participants in the mixed methods; studies with the enactive phenomenological framework usually have an number of participants between 4 and $13^{14,15,18,19,20,27,49,50,51}$. This particularity of in-depth qualitative research with case studies raises the question of generalization of the results. Thus, it is all the more interesting to cross this qualitative approach with a quantitative approach.

Finally, mixed methods inquiries pose problems on data articulation and on congruence between frameworks. The mix of methods can take different forms. It is not easy to compare quantitative and qualitative methods, to mix word and number. Some studies try to quantify qualitative data to help the comparison ${ }^{3,6}$. There are three kinds of mixed method analysis ${ }^{6}$. First, most mixed methods research uses analyses and interpretation conducted separately, as in the protocol presented here. Secondly, studies present separate analyses with some integration occurring during interpretation. Thirdly, a minority of studies integrate analyses and interpretation $(9 \%)^{6}$. The congruence between quantitative and qualitative frameworks is a huge debate between the purists, the situationalists, and the pragmatists. The pragmatists consider mixed method as a new way to understand the world, as a third paradigm which helps to bridge the separation between qualitative and quantitative methods ${ }^{52}$. Different relations exist between frameworks. On one side, there are researchers who study different noncongruent paradigms to give two different points of view on the same phenomenon. For example, in a study about the role of the referee in physical education ${ }^{32}$, researchers use two separate frameworks drawn from motivation and enactive phenomenology. On the other hand, other studies keep a "paradigm emphasis" 53,54 between frameworks. For example, in rowing performance, the enaction paradigm is used to connect enactive phenomenological with biomechanical approaches ${ }^{27}$. The phenomenological data serves to identify categories of oar strokes according to the rowers' point of view. The biomechanical data make it possible to determine mechanical signatures that are correlated with each phenomenological category. This kind of mixed method is close to a combined approach. Moreover, Johnson and Onwuegbuzie ${ }^{3}$ define mixed methods as a mix or a combination of approaches, concepts, techniques, methods, or language from quantitative and qualitative research into a specific inquiry. On this basis, combined approaches using qualitative and quantitative methods are a kind of mixed method. For example, a recent article summarizes the complex combinations of data using heterogeneous data with a common paradigm ${ }^{55}$. That study investigated two ways of collecting and analyzing interactions between trail runners and their equipment from online forums and from test protocol. Quantitative (e.g., indicators of the forum messages) data were combined with qualitative data (e.g., discussion contents, or enactive interviews) within the same enactive perspective. The results of that study suggest a method that designers can appropriate to analyze experiential data, which can then be integrated into the conception process.

This paper provides the foundation for future research to utilize mixed methods with a qualitative approach, to improve a protocol, evaluate a device, or give a cross vision of the same research subject.

\section{Disclosures}

The authors have nothing to disclose.

\section{Acknowledgements}

The authors thank Perrine Labeaume and Fanny Vieu for their help.

\section{References}

1. Creswell, J.W. A Concise Introduction to Mixed Methods Research. Sage Publications. New York, NY (2015).

2. Greene, J.C. Mixed Methods in Social Inquiry. John Wiley \& Sons. San Francisco, CA (2007).

3. Johnson, R.B., Onwuegbuzie, A.J. Mixed Methods Research: A Research Paradigm Whose Time Has Come, Mixed Methods Research: A Research Paradigm Whose Time Has Come. Educational Researcher. 33 (7), 14-26 (2004).

4. Arora, R., Stoner, C. A mixed method approach to understanding brand personality. Journal of Product \& Brand Management. 18 (4), 272-283 (2009).

5. Dunning, H., Williams, A., Abonyi, S., Crooks, V. A mixed method approach to quality of life research: A case study approach. Social Indicators Research. 85 (1), 145-158 (2008).

6. Greene, J.C., Caracelli, V.J., Graham, W.F. Toward a Conceptual Framework for Mixed-Method Evaluation Designs. Educational Evaluation and Policy Analysis. 11 (3), 255-274 (1989).

7. Kirschbaum, C., Pirke, K.-M., Hellhammer, D.H. The 'Trier Social Stress Test'-a tool for investigating psychobiological stress responses in a laboratory setting. Neuropsychobiology. 28 (1-2), 76-81 (1993).

8. Von Dawans, B., Kirschbaum, C., Heinrichs, M. The Trier Social Stress Test for Groups (TSST-G): A new research tool for controlled simultaneous social stress exposure in a group format. Psychoneuroendocrinology. 36 (4), 514-522 (2011).

9. Allen, A.P., Kennedy, P.J., Cryan, J.F., Dinan, T.G., Clarke, G. Biological and psychological markers of stress in humans: focus on the Trier Social Stress Test. Neuroscience \& Biobehavioral Reviews. 38, 94-124 (2014).

10. Birkett, M.A. The Trier Social Stress Test Protocol for Inducing Psychological Stress. Journal of Visualized Experiments. (56), e3238 (2011).

11. Dickerson, S.S., Kemeny, M.E. Acute stressors and cortisol responses: a theoretical integration and synthesis of laboratory research. Psychological Bulletin. 130 (3), 355-391 (2004).

12. Johnson, M.M. et al. A Modified Trier Social Stress Test for Vulnerable Mexican American Adolescents. Journal of Visualized Experiments. (125), e55393 (2017). 
13. Vors, O., Marqueste, T., Mascret, N. The Trier Social Stress Test and the Trier Social Stress Test for groups: Qualitative investigations. PLoS ONE. 13 (4), e0195722 (2018).

14. Rochat, N., Hauw, D., Antonini Philippe, R., von Roten, F.C., Seifert, L. Comparison of vitality states of finishers and withdrawers in trail running: An enactive and phenomenological perspective. PLoS ONE. 12 (3), e0173667 (2017).

15. Seifert, L. et al. Interpersonal Coordination and Individual Organization Combined with Shared Phenomenological Experience in Rowing Performance: Two Case Studies. Frontiers in Psychology. 8, 75 (2017).

16. Theureau, J. Le Cours D'action: L'enaction \& L'expérience. Octarès. Toulouse, France (2015).

17. Keegan, R.J., Harwood, C.G., Spray, C.M., Lavallee, D. A qualitative investigation of the motivational climate in elite sport. Psychology of Sport and Exercise. 15 (1), 97-107 (2014).

18. Doron, J., Bourbousson, J. How stressors are dynamically appraised within a team during a game: An exploratory study in basketball. Scandinavian Journal of Medicine \& Science in Sports. 27 (12), 2080-2090 (2016).

19. Ria, L., Sève, C., Saury, J., Theureau, J., Durand, M. Beginning teachers' situated emotions: A study of first classroom experiences. Journal of Education for Teaching. 29 (3), 219-234 (2003).

20. Sève, C., Ria, L., Poizat, G., Saury, J., Durand, M. Performance-induced emotions experienced during high-stakes table tennis matches. Psychology of Sport and Exercise. 8 (1), 25-46 (2007).

21. Durand, M. Activité humaine, pratiques sociales, et éducation des adultes. In Un Dialogue Entre Concepts et Réalité. Edited by Friedrich, J., Pita, J., 13-37, Edition Raison \& Passions. Dijon, France (2014).

22. Thompson, E. Sensorimotor subjectivity and the enactive approach to experience. Phenomenology and the cognitive sciences. 4 (4), $407-427$ (2005).

23. Varela, F., Rosch, E., Thompson, E. The Embodied Mind: Cognitive Science and Human Experience. MIT Press. Cambridge, MA (1992).

24. Froese, T., Di Paolo, E.A. The enactive approach: Theoretical sketches from cell to society. Pragmatics \& Cognition. 19 (1), 1-36 (2011).

25. Theureau, J. Course-of-action analysis and course-of-action centered design. In Handbook of Cognitive Task Design. Edited by Hollnagel, E., 55-81, CRC Press. Boca Raton, FL (2003).

26. De Jaegher, H., Di Paolo, E. Participatory sense-making. Phenomenology and the Cognitive Sciences. 6 (4), $485-507$ (2007).

27. R'Kiouak, M., Saury, J., Durand, M., Bourbousson, J. Joint Action of a Pair of Rowers in a Race: Shared Experiences of Effectiveness Are Shaped by Interpersonal Mechanical States. Frontiers in Psychology. 7 (2016).

28. Hauw, D. Antidoping education using a lifelong situated activity-based approach: evidence, conception, and challenges. Quest. 69 (2), 256-275 (2017).

29. Horcik, Z., Savoldelli, G., Poizat, G., Durand, M. A Phenomenological Approach to Novice Nurse Anesthetists' Experience During SimulationBased Training Sessions. Simulation in Healthcare - Journal of the Society for Simulation in Healthcare. 9 (2), 94-101 (2014).

30. Vors, O., Gal-Petitfaux, N. Relation between students' involvement and teacher management strategies in French "difficult" classrooms. Physical Education and Sport Pedagogy. 20 (6), 647-669 (2015).

31. Vors, O., Gal-Petitfaux, N., Potdevin, F. A successful form of trade-off in compensatory policy classrooms: Processes of ostentation and masking. A case study in French physical education. European Physical Education Review. 21 (3), 340-361 (2015).

32. Adé, D., Ganière, C., Louvet, B. The role of the referee in physical education lessons: student experience and motivation. Physical Education and Sport Pedagogy. 23 (4), 418-430 (2018).

33. Lesage, F.-X., Berjot, S., Deschamps, F. Psychometric properties of the French versions of the Perceived Stress Scale. International Journal of Occupational Medicine and Environmental Health. 25 (2), 178-184 (2012).

34. Salama-Younes, M., Montazeri, A., Ismaïl, A., Roncin, C. Factor structure and internal consistency of the 12-item General Health Questionnaire (GHQ-12) and the Subjective Vitality Scale (VS), and the relationship between them: a study from France. Health and Quality of life Outcomes. 7 (1), 22 (2009).

35. Goodman, W.K., Janson, J., Wolf, J.M. Meta-analytical assessment of the effects of protocol variations on cortisol responses to the Trier Social Stress Test. Psychoneuroendocrinology. 80, 26-35 (2017).

36. Allen, A.P. et al. The Trier Social Stress test: principles and practice. Neurobiology of Stress. 6, 113-126 (2017).

37. Spielberger, C.D., Gorsuch, R.L., Lushene, R.E. Manual for the State-Trait Anxiety Inventory (Self-evaluation Questionnaire). Palo Alto, CA (1970).

38. Bradley, M.M., Lang, P.J. Measuring emotion: the self-assessment manikin and the semantic differential. Journal of Behavior Therapy and Experimental Psychiatry. 25 (1), 49-59 (1994).

39. Frisch, J.U., Häusser, J.A., Dick, R. van, Mojzisch, A. The Social Dimension of Stress: Experimental Manipulations of Social Support and Social Identity in the Trier Social Stress Test. Journal of Visualized Experiments. (105), e53101 (2015).

40. Starks, H., Brown Trinidad, S. Choose your method: A comparison of phenomenology, discourse analysis, and grounded theory. Qualitative Health Research. 17 (10), 1372-1380 (2007).

41. Mascret, N. et al. The Influence of the "Trier Social Stress Test" on Free Throw Performance in Basketball: An Interdisciplinary Study. PLoS ONE. 11 (6), e0157215 (2016)

42. Het, S., Rohleder, N., Schoofs, D., Kirschbaum, C., Wolf, O.T. Neuroendocrine and psychometric evaluation of a placebo version of the 'Trier Social Stress Test.' Psychoneuroendocrinology. 34 (7), 1075-1086 (2009).

43. Nater, U.M. et al. Performance on a declarative memory task is better in high than low cortisol responders to psychosocial stress. Psychoneuroendocrinology. 32 (6), 758-763 (2007).

44. Adé, D., Poizat, G., Gal-Petitfaux, N., Toussaint, H., Seifert, L. Analysis of elite swimmers' activity during an instrumented protocol. Journal of Sports Sciences. 27 (10), 1043-1050 (2009).

45. Poizat, G., Adé, D., Seifert, L., Toussaint, H., Gal-Petitfaux, N. Evaluation of the Measuring Active Drag system usability: An important step for its integration into training sessions. International Journal of Performance Analysis in Sport. 2 (10), 170-186 (2010).

46. Seifert, L. et al. Neurobiological degeneracy and affordance perception support functional intra-individual variability of inter-limb coordination during ice climbing. PLoS ONE. 9 (2), e89865 (2014).

47. Legrand, D. Pre-reflective self-as-subject from experiential and empirical perspectives. Consciousness and Cognition. 16 (3), $583-599$ (2007).

48. Mangan, B. Taking Phenomenology Seriously: The "Fringe" and Its Implications for Cognitive Research. Consciousness and Cognition. 2 (2), 89-108 (1993).

49. Mohamed, S., Favrod, V., Antonini Philippe, R., Hauw, D. The Situated Management of Safety during Risky Sport: Learning from Skydivers' Courses of Experience. Journal of Sports Science and Medicine. 14 (2), 340-346 (2015). 
50. Mottet, M., Eccles, D.W., Saury, J. Navigation in outdoor environments as an embodied, social, cultural, and situated experience: An empirical study of orienteering. Spatial Cognition \& Computation. 16 (3), 220-243 (2016).

51. Antonini Philippe, R., Rochat, N., Vauthier, M., Hauw, D. The story of withdrawals during an ultra-trail running race: A qualitative investigation of runners' Courses of experience. The Sport Psychologist. 30 (4), 361-375 (2016).

52. Onwuegbuzie, A.J., Leech, N.L. On becoming a pragmatic researcher: The importance of combining quantitative and qualitative research methodologies. International Journal of Social Research Methodology. 8 (5), 375-387 (2005).

53. Morgan, D.L. Practical strategies for combining qualitative and quantitative methods: Applications to health research. Qualitative Health Research. 8 (3), 362-376 (1998).

54. Morse, J.M. Approaches to qualitative-quantitative methodological triangulation. Nursing Research. 40 (2), 120-123 (1991).

55. Rochat, N., Hauw, D., Seifert, L. Enactments and the design of trail running equipment: An example of carrying systems. Applied Ergonomics. (2018). 